\title{
Mössbauer, XRD and positron annihilation studies on natural magnetite and hematite ore from Ari Dongri, Central India
}

\author{
D DAS ${ }^{1}, \mathrm{M}$ B CHAKRABORTI ${ }^{2}, \mathrm{~K}^{\mathrm{C}}$ CHOUDHURY ${ }^{1}$, \\ P M G NAMBISSAN ${ }^{3}$, B R S BABU ${ }^{3 *}$, P SEN $^{3}$, SANGEETA ${ }^{4}$ \\ and $C \mathrm{~K}$ MAJUMDAR ${ }^{5}$ \\ ${ }^{1}$ Department of Solid State Physics, Indian Association for the Cultivation of Science, \\ Jadavpur, Calcutta 700032, India \\ ${ }^{2}$ Geology Department, Presidency College, Calcutta 700 073, India \\ ${ }^{3}$ Cyclic Accelerator Divișion, Saba Institule of Nuclear Physics, Calcuttu 700009 , India \\ *Technical Physics and Prototype Engineering Division, Bhabha Atomic Research Centre, \\ Trombay, Bombay 400085 , India \\ ${ }^{5} \mathrm{~S}$ N Bose National Centre for Basic Sciences, Calcutta 700064 , India \\ * Or leave of abscnce from Department of Physics, Calicut Univarsity, Calicut 673635 , India
}

MS recetved 21 September 1989; revised 5 July 1991

\begin{abstract}
Alstract. Natural magnetite and hematite samples taken from iron ore deposits associated with Precambrian banded iron-formation (BIF) at Ari Dongri $\left(20^{\circ} 23^{\prime} \mathrm{N}: 81^{\circ} 3^{\prime} \mathrm{E}\right.$ ), Bastar district in Central lndia have been studied by Mössbauer, XRD and positron annihilation techniques. Three magnelite samples show a genetic association with $\alpha-\mathrm{Fe}_{2} \mathrm{O}_{3}$ with a wide range of variations in $\mathrm{Fe}_{3} \mathrm{O}_{4}: \alpha-\mathrm{Fe}_{2} \mathrm{O}_{3}$ ratio. The fourth sample, an typical specular hematite, shows $\alpha-\mathrm{Fe}_{2} \mathrm{O}_{3}$ content of the order of $90 \%$, the rest being magnetite. The magnetite present in the samples was found to he stoichiometric. None of the samples contains maghenite $\left(\gamma-\mathrm{F}_{2} \mathrm{O}_{3}\right)$. Some geological implications of the observed variation in the oxidation states of the samples are considered.
\end{abstract}

Keywords. Mössbauer; X-ray diffraction; positron; magnetite; hematite ore.

\section{Introduction}

Iron oxide minerals are sensitive indicators of physicochemical conditions (e.g. temperature, pressure and $\mathrm{Eh}-\mathrm{pH}$ stales of the environment) prevailing during their formation and subsequent events. Mossbauer spectroscopy enables us to identify their phase assemblages and determine their precise oxidation states (Bancroft 1973). Earlier we reported the results of Mössbauer studies on a chlorite-sideritc-magnetite assemblage developed under low temperature-pressure conditions in 'green shale' of Precambrian sedimentary banded iron formation (BIF) of South Singbhum, Eastern India (Das et al 1986). In this paper we present the result of Mössbauer studies of oxide facies viz. some magnetite and hematite samples collected from the iron deposits of a Precambrian metamorphosed BIF at Ati Dongri $\left(20^{\circ} 23^{\prime} \mathrm{N}: 81^{\circ} 3^{\prime} \mathrm{E}\right)$, Bastar district, Madhya Pradesh, India. X-ray diffraction and positron annihilation measurements in the same samples supplement and confirm the findings of the Mössbauer method.

The iron formation hosting the hematile and magnetite deposits belongs to a sequence of metasedimentary and metavolcanic rocks occurring within a granitegneissic terrain and suffered deformation and progressive regional metamorphism. These were also affected by late phase basic and acidic igneous intrusions (Mukharya 1975). BIF has an oxide-facies mineral association (hematite and magnetite) with only 
minor content of silicates and sulphides. The ore deposits comprising hard microplaty (specular) hematite ore and hard granular magnetite ore are genetically related to banded hematite quartz rock and ferruginous argillite (metamorphosed clayey rock). The hematite ore shows clear evidence of having undergone deformation (e.g. development of schistosity, puckering, lineation etc.) aiong with the host BIF, thus being pre-tectonic. The magnetite ore, in contrast, is free of any such deformational imprint and apparently post-dates the peak of deformation. Magnetites, however, are associated with high temperature minerals iike sillimanite $\left(\mathrm{Al}_{2} \mathrm{SiO}_{5}\right)$ and cordierite $\left(\mathrm{Mg}-\mathrm{Fe}^{2+}-\mathrm{Al}\right.$-silicate) and at places, even with muscovite and pyritc $\left(\mathrm{FeS}_{2}\right)$.

Our interest centres on the ratio of $x-\mathrm{Fe}_{2} \mathrm{O}_{3}$ to $\mathrm{Fe}_{3} \mathrm{O}_{4}$ and the ratio of $\mathrm{Fe}^{2+}$ to $\mathrm{Fe}^{3+}$ in the bulk ore sample and on evaluating their variations in terms of possitile natural processes. A rolated information required would be the presence, if at all, of maghemite or $\gamma-\mathrm{Fe}_{2} \mathrm{O}_{3}$. All these would throw more light on the precise oxidation state of the constituent minerals in the ore and their paragenetic relationship.

\section{Experimental procedure}

\subsection{Description of the sampies}

Four lield samples $S_{1}, S_{2}, S_{3}$ (all nominally magnetite) and $S_{4}$ (nominally hematite) are the materials lor the present study. $S_{1}$ is associated with pyrite, $S_{2}$ is apparently whoily magnetite, whereas $S_{3}$ has muscovite in association. Magnetic strength appears to diminish in the samples from $S_{1}$ to $S_{3} . S_{4}$ is a typical microplaty specular hematite (with sparsely scattered cosrse magnetite cuhedra) but the bulk sample is found to be weakly magnetic.

Examination of the samples under microscope in the reflected light revcals the following mineralogical and textural characters.

Sample $S_{1}$ contains magnetite as the predominant phase in association with a younger hematite phase, occasionally engulfing almost the entire magnetite parent, Replacement is broadly controlled along (111) parting planes, but nowhere in fine detail, and thus the intricate "cloth-texture' type replacement (a common weathering feature) is totally absent. Pyrite present as an additional phase in $S_{1}$ shows replacement relationship with magnetite. Samples $S_{2}$ and $S_{3}$ show the presence of magnetite with different degress of martitization in intricately fine detail along (111) planes (clothtexture typel. Minor amount of goethite/limonite is present in these 1 wo samples. The hematite sample $\mathrm{S}_{4}$ mainly contains microplaty hematitc along with minute irregular relics of magnetite at the core of many hematite grains which point to their derivation from older magnetite. $S_{4}$ is, lowever, not cogenetic with $S_{1}, S_{2}$ and $S_{3}$ and belongs to a diferent ore body. In addition, there occur a few isolated large magnetite euhedra which texturally bear evidence of a thermal history (Ramdohr 1980), crosscut the plane structure of hematite and indicate reversal of oxidation; however, these have not been included in the present study.

\subsection{Experimental details}

Each sample was crushed and the iron oxide minerals were separated from garlgue and impurities other than iron oxides by a strong hand magnct. In the present case, 
the hematite sample $S_{4}$ posed no problem owing to its magnetic property and the textural character described earlier. The separated parts were then washed several limes with distilled water, dried at room temperature and allowed to pass through a 30 sieve mesh. 'These powders were used for all experimental measurements.

Each Mössbauer measurement was carried out with $30 \mathrm{mg}$ of the powder sandwiched between two thin cellophane papers. All measurements were made at room temperature in transmission geometry. A typical 512 channel multichannel analyser coupled to a precision velocity drive system (supplied by $\mathrm{M} / \mathrm{s}$ Wissel, West Germany) was used to record the spectra. The source used was is $3 \mathrm{mCl}{ }^{57} \mathrm{Co}$ in $\mathrm{Rh}$ matrix. The calibration or the spectrometer was done by noting the peak positions of a pure natural iron foil. The Mössbauer spectra were analysed by a least squares fit program based on that of von Meerwaal (1975) on an IRIS-80 computer.

$X$-ray diffractograms of the powder samples were taken on a Philips (PW 1710) diffractometer using Cu- $\mathrm{K}_{\mathrm{a}}$ radialion.

For positron lifetime measurements a weak $(\sim 2 \mu \mathrm{Cj}){ }^{22} \mathrm{Na}$ positron source evaporated on a thin $\mathrm{Ni}$ foil and covered by an identical $\mathrm{Ni}$ foil was used. To minimize the contribution from air and absorbcd gases, all the powders of the samples were degassed by heating at $100^{\circ} \mathrm{C}$ in vacuum for at least $2 \mathrm{~h}$ before starting any measurements. The positron source was placed centrally in a glass degassing chamber and the powder was poured around the source so as to have all the positrons annihilate in the powder specimen. The source-sample assembly was kept under vacuum throughout the duration of measurements which lasted about $16 \mathrm{~h}$ for every sample studied.

The positron lifetime measurements were performed using a conventional slow last coincidence spectromecer. The prompt time resolution (fwhm) of the spectrometer was $260 \mathrm{ps}$ for ${ }^{60} \mathrm{Co}$ gamma rays at the positron cxperimental window settings of the upper $50 \%$ of the Compton emission accepted in both the channels. The lifetime spectra were analysed by using the computer programs POSITRONFIT and RESOLUTION (Kirkegaard and Eldrup 1974, 1979). A source component of intensity $10 \%$ was removed from all the lifetime spectra.

\section{Results and discusșion}

\subsection{Mössbauer studies}

Figure 1 shows the Mössbauer spectra recorded at room temperature of the powders studied. Three sextets were fitted to the experimental points to get a good $\chi^{2}$ value for all samples. The six finger patterns with hyperfine field $492 \pm 3 \mathrm{kOe}$ and $459 \pm 3 \mathrm{kOe}$ with isomer shifts (IS) $0.22 \div 0.04 \mathrm{~mm} / \mathrm{s}$ and $0.66 \pm 0.04 \mathrm{~mm} / \mathrm{s}$, respectively, are identilied as due to magnetite $\left(\mathrm{Fc}_{3} \mathrm{O}_{4}\right)$; the former comes from the $\mathrm{Fe}^{3+}$ atoms at tetrahedral (A) site, the latter is due to both $\mathrm{Fe}^{2+}$ and $\mathrm{Fe}^{3+}$ at octahedral (B) site (Danniels and Rosencwaig 1969). The resonance areas under the $\mathrm{A}$ site and $\mathrm{B}$ site peaks, which are directly proportional to the number of iron atoms in corresponding sites, are evaluated and the ratio $\mathrm{Fe}(\mathrm{A}): \mathrm{Fe}(\mathrm{B})$ is found to be $\simeq 0.5$. This and the general shape of the spectra indicate that all these samples are stoichiometric magnetite with no appreciable vacancy at octahedral sites. The third sextet with hyperfine field $515 \pm 3 \mathrm{kOe}$ and IS $=0.30 \pm 0.04 \mathrm{~mm} / \mathrm{s}$ and quadruple splitting $(\mathrm{QS})=0.28 \pm 0.04 \mathrm{~mm} / \mathrm{s}$ 


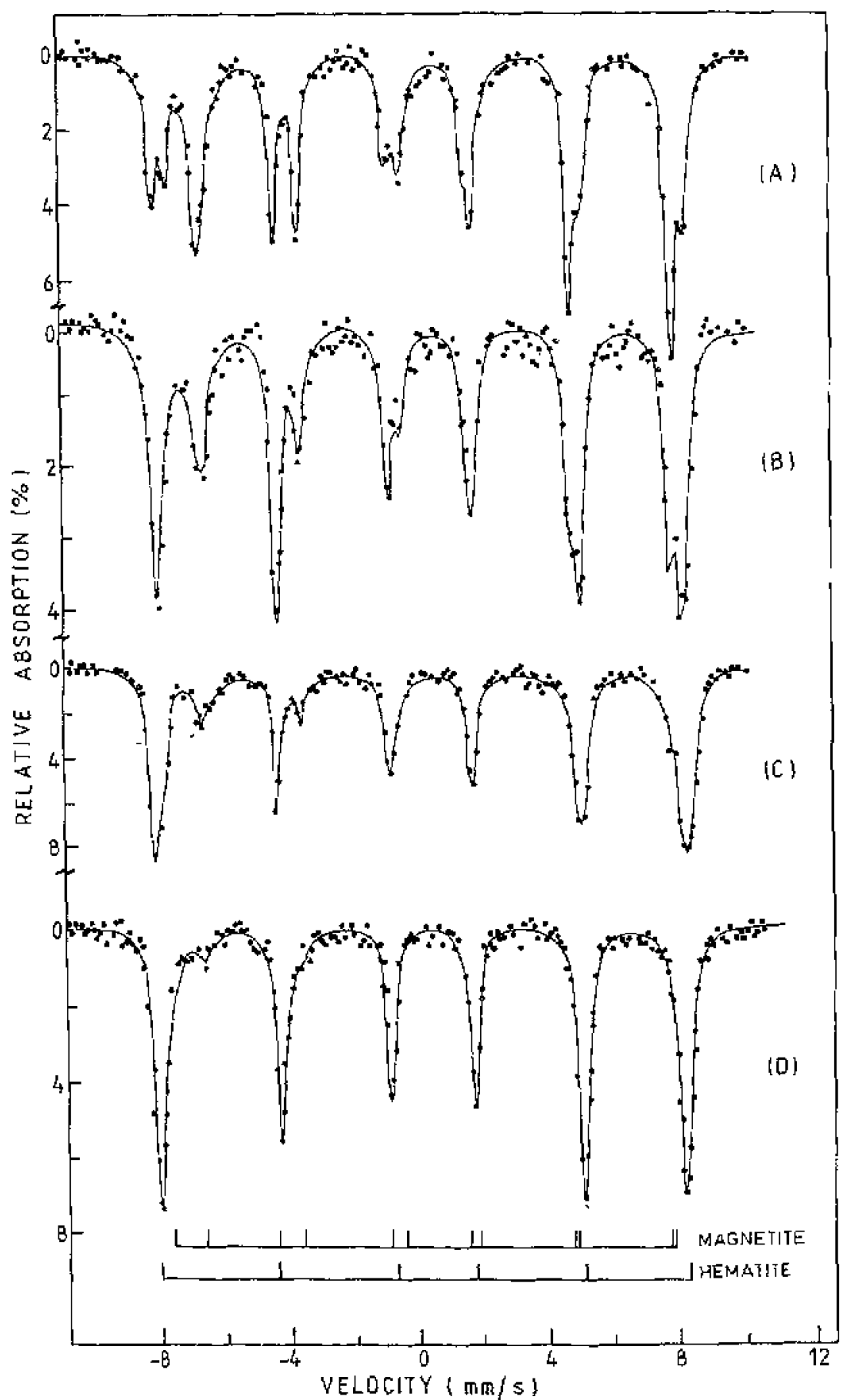

Figure 1. Mōssbauer spectra of the powders: (A) sample $s_{1},(B)$ sampie $S_{2},(C)$ sample $S_{3}$ and (D) sample $S_{4}$. 
Table 1. Relative amounts of $\alpha-\mathrm{Fe}_{2} \mathrm{O}_{3}$ and $\mathrm{Fe}_{3} \mathrm{O}_{4}$ phases calculated from Mössbauer resonance areas and $\mathrm{Fe}^{3+}: \mathrm{Fe}^{2+}$ ritlio.

\begin{tabular}{|c|c|c|c|}
\hline Sample & $\%$ of $\mathrm{Fe}_{3} \mathrm{O}_{4}$ & $\because$ of $x-\mathrm{Fe}_{2} \mathrm{O}_{3}$ & $\begin{array}{c}\mathrm{Fe}^{3-} / \mathrm{Fc}^{2+} \\
\text { in tho bulk } \\
\text { sample }\end{array}$ \\
\hline $\mathbf{S}_{1}$ & 70 & 30 & $76: 24$ \\
\hline$S_{2}$ & 52 & 48 & $82: 18$ \\
\hline$S_{3}$ & 25 & 75 & $92: 8$ \\
\hline$S_{1}$ & 10 & 90 & $96: 4$ \\
\hline
\end{tabular}

Error in arca measurements $=:-3 \%$

is identified as due to hematite $\left(\alpha-\mathrm{Fc}_{3} \mathrm{O}_{3}\right)$. Assuming the same Lamb-Mössbauer factors for $\alpha-\mathrm{Fe}_{2} \mathrm{O}_{3}$ and $\mathrm{Fe}_{3} \mathrm{O}_{4}$ the relative amounts of $\alpha-\mathrm{Fe}_{2} \mathrm{O}_{3}$ and $\mathrm{Fe}_{3} \mathrm{O}_{4}$ in the powders were calculated from the resonance areas and the $\mathrm{Fe}^{3+} / \mathrm{Fe}^{2+}$ ralios wcre obtained from them. The results are shown in table 1.

\section{$3.2 X R D$ analysis}

The X-ray dilftactograms of the powders were recorded to check the Mössbauer findings. Figure 2 shows a typical diffraction pattern recorded for the sample $S_{1}$. Other samples show similar patterns. The $d$ values calculated from the intense peaks observed are shown in table 2 . Comparing the calculated $d$ values and the relative intensities of the different peaks to those feported for pure $\mathrm{Fe}_{3} \mathrm{O}_{4}$ and $\alpha-\mathrm{Fe}_{2} \mathrm{O}_{3}$, we conclude that all the samples contain both $\mathrm{Fe}_{3} \mathrm{O}_{4}$ and $\alpha-\mathrm{Fe}_{2} \mathrm{O}_{3}$. Comparison of the peak intersities of the four recorded diffraction patterns indicates that the $\mathrm{Fe}_{3} \mathrm{O}_{4}: \alpha-\mathrm{Fe}_{2} \mathrm{O}_{3}$ ratio gradually decreases in the samples, being highest in $\mathrm{S}_{1}$ and lowest in $\mathrm{S}_{4}$. All these support the Mössbauer spectroscopic observations.

\subsection{Positron lifetime study}

Natural magnetite sample may very often contain maghemite $\gamma-\mathrm{Fe}_{2} \mathrm{O}_{3}$ (Wasilcwskt 1979). Our Mössbauer and X-ray data indicate that maghemite is not present in any of the samples studied. The conclusion is supported by positron annibilation studies.

It is not always possible to detect $\gamma-\mathrm{Fe}_{2} \mathrm{O}_{3}$ in a sample by Mössbauer spectroscopy, particularly when associaled with $\mathrm{Fe}_{3} \mathrm{O}_{4}$ and $\alpha-\mathrm{Fe}_{2} \mathrm{O}_{3}$, because of the strong overlapping of the characteristic lines. XRD analysis also may lead to confusion while detecting $\gamma-\mathrm{Fe}_{2} \mathrm{O}_{3}$ in the presence of $\mathrm{Fe}_{3} \mathrm{O}_{4}$ becuuse both have cubic structure and very close lattice constants (for $\mathrm{Fe}_{3} \mathrm{O}_{4} a=9-397 \AA$; for $\gamma-\mathrm{Fe}_{2} \mathrm{O}_{3} a=8.33 \AA$ ). Maghemite $\left(y-\mathrm{Fe}_{2} \mathrm{O}_{3}\right)$ actually is extremeiy non-stoichiometric $\mathrm{Fe}_{3} \mathrm{O}_{4}$ which can be represented as

$$
\left[\mathrm{Fe}^{3+}\right]_{\mathrm{tel}}\left[\mathrm{Fe}_{1+2 x}^{3+} \mathrm{Fe}_{1-3 x}^{2+} \square_{x}\right]_{\mathrm{oct}} \mathrm{O}_{4}
$$

$x=0.33$ (Coey et al 1971). Here $\square$ means vacancies present at the octahedral (B) site, Positron lifetime studics in other oxides have shown a larger lifetime component for a yacancy rich sample (Brauer et al 1984). Hence for $\gamma-\mathrm{Fe}_{2} \mathrm{O}_{3}$ which is nothing but vacancy-rich $\mathrm{Fe}_{3} \mathrm{O}_{4}$; one expects a lifetime larger in comparison to that in a defect-free 


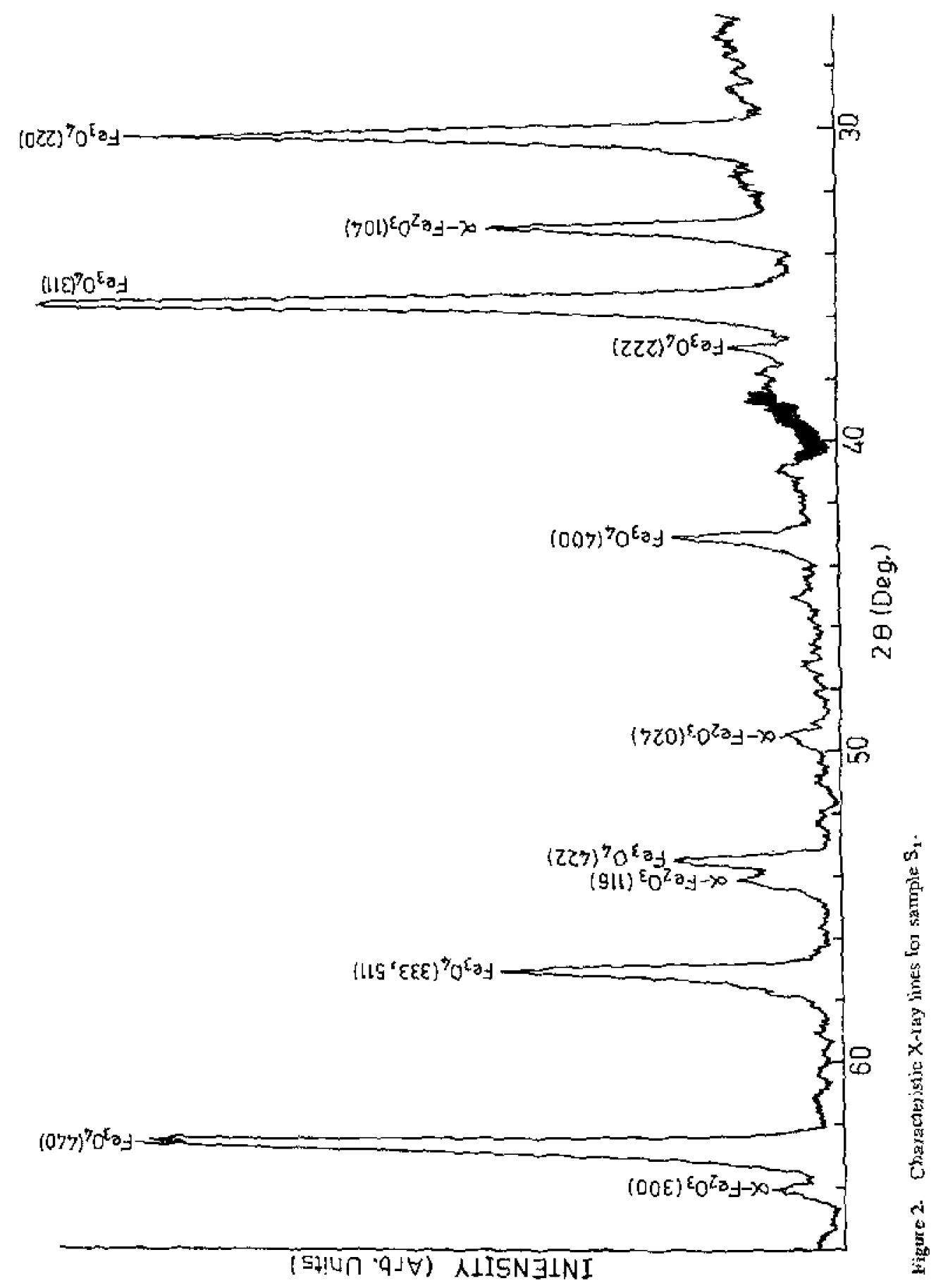


Table 2. X-ray diffraction results.

\begin{tabular}{|c|c|c|c|c|c|}
\hline Pure $\mathrm{Fe}_{3} \mathrm{O}_{4}{ }^{*}$ & Pure $\mathrm{Fe}_{2} \mathrm{O}_{3}{ }^{*}$ & $s_{1}$ & $\mathrm{~S}_{2}$ & $S_{3}$ & $\mathrm{~S}_{4}$ \\
\hline \multirow{2}{*}{$\begin{array}{l}2966 \\
(70)\end{array}$} & & 298 & & $2 \cdot 96$ & 2.97 \\
\hline & $\begin{array}{l}2.690 \\
(100)\end{array}$ & $2 \cdot 69$ & $2 \cdot 69$ & $2 \cdot 69$ & 2.71 \\
\hline \multirow{3}{*}{$\begin{array}{l}2.530 \\
(100)\end{array}$} & & $2 \cdot 52$ & 2.53 & $2 \cdot 53$ & $2 \cdot 54$ \\
\hline & $\begin{array}{r}2510 \\
(50)\end{array}$ & & $2 \cdot 51$ & & $2 \cdot 53$ \\
\hline & $\begin{array}{r}2.210 \\
(30)\end{array}$ & & & $2 \cdot 20$ & $2 \cdot 21$ \\
\hline \multirow[t]{2}{*}{$\begin{array}{l}2.096 \\
(70)\end{array}$} & & 209 & $2 \cdot 08$ & & $2 \cdot 10$ \\
\hline & $\begin{array}{r}1838 \\
{[40)}\end{array}$ & 1.84 & 1.83 & 1.84 & 1.84 \\
\hline \multicolumn{6}{|l|}{$\begin{array}{l}1.712 \\
(60)\end{array}$} \\
\hline & $\begin{array}{r}1.690 \\
(60)\end{array}$ & 1.69 & $1 \cdot 68$ & $1 \cdot 69$ & $1-69$ \\
\hline $\begin{array}{l}1-614 \\
(85)\end{array}$ & & $1 \cdot 6[$ & & $1 \cdot 61$ & \\
\hline (85) & $\begin{array}{r}1 \cdot 484 \\
(35)\end{array}$ & 1.48 & 1.48 & 1.48 & $1-48$ \\
\hline \multirow[t]{2}{*}{$\begin{array}{l}1 \cdot 483 \\
(85)\end{array}$} & & & & & \\
\hline & $\begin{array}{r}1.452 \\
(35)\end{array}$ & 1.44 & 1.44 & 1.45 & \\
\hline $\begin{array}{l}1.092 \\
(60)\end{array}$ & & & & & \\
\hline
\end{tabular}

The $d$ values are in Angstroms. The observed lines at 1.69 and 1.48 ate probably overlapping lines from $\mathrm{Fe}_{3} \mathrm{O}_{4}$ and $\alpha-\mathrm{Fe}_{2} \mathrm{O}_{3}$. " Data from Berry (1974).

sample. Keeping this in mind we have examined the present samples by positron annihilation technique. Figure 3 shows a typical positron lifetime distribution curve for sample $\mathrm{S}_{1}$ along with the prompt time resolution. Since the samples are mixtures of different iron oxides, only the mean lifetime $\left(\tau_{m}\right)$ values are meaningful. Table 3 shows the lifetimes and corresponding intensities of the components. A two-component fit is made to the experimental data as it gave a better $\chi^{2}$ value. To compare the lifetimes observed for the samples studied, one $\mathrm{Fe}_{3} \mathrm{O}_{4}$ and one $\gamma-\mathrm{Fe}_{2} \mathrm{O}_{3}$ sample found to be pure by both Mössbauer and XRD analysis ate used as reference. The observed mean lifetime of $199 \mathrm{ps}$ for $\mathrm{S}_{1}$ is very close to the reference $\mathrm{Fe}_{3} \mathrm{O}_{4}$ lifetime value suggesting that $\mathrm{Fe}_{3} \mathrm{O}_{4}$ is the major part in it. $\mathrm{S}_{2}$ shows a mean lifetime $215 \mathrm{ps}$ which is midway between the lifetimes of the reference samples indicating that the sample contained appreciable anounts of $\mathrm{Fe}_{3} \mathrm{O}_{4}$ and $\alpha-\mathrm{Fe}_{2} \mathrm{O}_{3}$. For $\mathrm{S}_{3}$ the lifetime observed is $221 \mathrm{ps}$. This being close to the reference $\alpha-\mathrm{Fe}_{2} \mathrm{O}_{3}$ lifetime indicates that $\mathrm{S}_{3}$ contains mainly hematite. For $\mathrm{S}_{4}$ the lifetime observed is $191 \mathrm{ps}$. Though the Mössbauer and XRD results show the sample to be a mixture of $\alpha-\mathrm{Fe}_{2} \mathrm{O}_{3}$ and $\mathrm{Fe}_{3} \mathrm{O}_{4}$, the remarkably low mean lifetime (even less than $197 \mathrm{ps}$ observed in $\mathrm{Fe}_{3} \mathrm{O}_{4}$ ) implies larger particle size for this sample in comparison to the other samples studied. It is known that the 


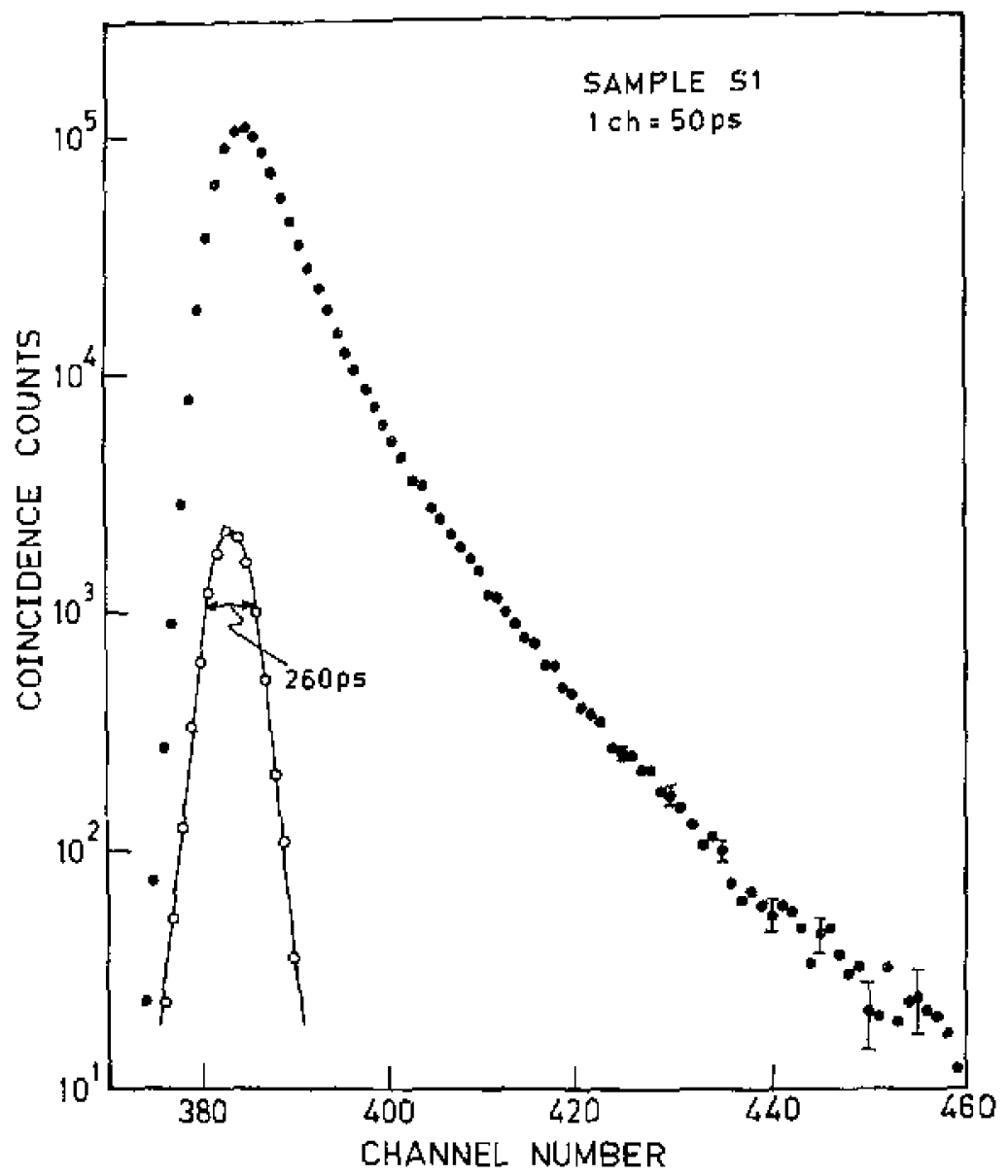

Figure 3. Positron lifetime spectrun in sample $S_{1}$.

Table 3. Results of positron lifetime studies. $\tau_{1}$ and $\tau_{2}$ are the two lifetimes, $I_{2}$ the intensity of the second hifetirat component $\tau_{2}, \tau_{m}$ is the mean lifetime.

\begin{tabular}{|c|c|c|c|c|}
\hline Sample & $\mathrm{\tau}_{2}(\mathrm{ps})$ & $\tau_{2}(\mathrm{ps})$ & $l_{7}(\%)$ & $\tau_{m}(\mathrm{ps})$ \\
\hline Purc $\mathrm{Fe}_{3} \mathrm{O}_{4}$ & 140 & 289 & 38 & 197 \\
\hline Pure $\alpha-F e_{2} O_{3}$ & 173 & 352 & 28 & 224 \\
\hline $\mathrm{S}_{\mathrm{I}}$ & 131 & 273 & 43 & 199 \\
\hline $\mathrm{S}_{2}$ & 154 & 337 & 33 & 215 \\
\hline$S_{3}$ & 164 & 367 & 28 & 221 \\
\hline$S_{4}$ & 140 & 305 & 31 & 191 \\
\hline
\end{tabular}

Typical errors in $\mathrm{T}_{1}= \pm 3 \mathrm{ps}, \tau_{2}= \pm 5 \mathrm{ps}, I_{2}= \pm 3 \%$ and $\tau_{m}= \pm 8 \mathrm{ps}$. 
Finer the particle size the larger is the lifetime (Mitsuhashi et al 1972). The observed lifetimes for the samples also rule out the presence of $\gamma-\mathrm{Fe}_{2} \mathrm{O}_{3}$ in them as none of them show enhanced mean lifetime which would be expected if positrons were trapped at cation vacancies present in $\gamma-\mathrm{Fe}_{2} \mathrm{O}_{3}$. Thus the Mössbauler analysis of filting only three sextets to the experimental points, one for $\alpha-\mathrm{Fe}_{2} \mathrm{O}_{3}$ and two for $\mathrm{Fe}_{3} \mathrm{O}_{4}$ are justified.

\section{Conclusions}

The observed results reveal the presence of $\mathrm{Fe}_{3} \mathrm{O}_{4}$ and $\alpha-\mathrm{Fe}_{2} \mathrm{O}_{3}$ in the samples and yield a quantitative relative estimation of the phases in these iron ores. The magnetite present in all the samples is found to be stoichionetric. The samples show large flucluations in the oxidation states and the $\mathrm{Fe}^{2+} / \mathrm{Fe}^{3+}$ ratios.

The presence of $30 \%$ hematite in $\mathrm{S}_{1}$, which texturally bears no sign of weathering, indicates that the magnetite ore in the locality has suffered decp-seated oxidation (hypogene martitization) during the metamorphic cycle. This may have occurred in $\mathrm{S}_{2}$ and $\mathrm{S}_{3}$ also, but the evidence of the ore texture of these samples suggests that their additional hematite is partly due to weathering. Ready transfer to the highest oxidation state in them is probably due to the replacement of magnetite by secondary pseudomorphous hematite (supergene martitization) caused by oxygen-bearing surface water (meteoric water) percolating to different depths. The transformation takes place along the (111) planes as the (111) planes of the ccp structure of magnetite are equivalent to the (001) planes of the hcp structure of bematite. The hematite in $S_{4}$ arises from the conversion of magnetite under high temperature-pressure conditions in a hydrous environment (Kalliokoski 1965; Mel'nik 1982). The absence of maghemite indicates high temperature conditions during ore formation, as maghemite is known to be unstable above $500^{\circ} \mathrm{C}$. More cannot be said from the present exploration with a few samples, but a more detailed study seems to be worthwhile.

\section{Acknowledgements}

The authors would like to thank Professor M K Bose of Presidency College, Calcutta, For this constructive criticism in the analysis of the ore samples. Thanks are due to Professor S P Sengupta of IACS, Calcutta; Dr D R Dasgupta of Jadavpur University; Dr B Ghosh of TPPED Division, BARC, Bombay; Sri S Chatterjee of SINP, Calcutta and Sri T Bandyopadhyay of VECC, Calcutta for providing various technical assistance in carrying out the work.

\section{References}

Bancroft G M 1973 Mössbauer spectroscopy (London: McGraw Hill)

Berry' L G (ed.) 1974 Powder diffraction file (Phtladelphia: Joint Committee on Powder Diffraction Standards)

Bracer G, Kerbe F, Kajcsos Zs and Ashry A 1984 Phys, Statws, Solidi A84 451

Coey J M D, Morrish A H and Sawatzky G A 1971 J. Phys. (Parls) C1 271 
Danniejs J M and Rosencwaig A 1969 Phys. Chem. Solids 301561

Das D, Chakrebarti M B, Majumdar C K and Bose M K 1986 Pramāna-J. Phys. 27331

Kalliokoski J 1965 Ecdr. Geol. 60100

Kirkegaard P and Eldrup M 1974 Comp. Phys. Commun. $7401 ; 1979$ Riso report

Mel'nik Y P 1982 Precambrian banded iron-formations (Eisevier: Developments in Precambrian Geology) vol. 5

Mitsuhasai T, Noguchi M, Chiba T, Ono A, Masaki I and Tsuda N 1972 J. Phys Soc. Jph. 321281

Mukbarya I I 1975 Geol. Soc. India 16441

Rasndobr P 1980 The ore minerals and their intergrowths, Second edition, vol. 2 (Oxford: Pergamon Press)

Smirnor' Y I 1976 Geulogy of mineral deposits (Moscow: Mir publishers)

von Meewall E 1975 Comp. Phys. Commun. 9117

Wasilewski P J 1979 Appl. Phys. 502428 